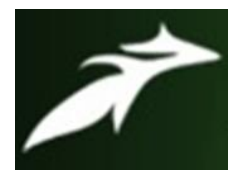

M.G. Puri et al, International Journal of Advances in Agricultural Science and Technology,

Vol.8 Issue.1, January-2021, pg. 23-28

ISSN: 2348-1358

Impact Factor: 6.057

NAAS Rating: 3.77

\title{
Constraints Faced by the Farmers in Adaptation Activities in Response to Climate Change and their Suggestions to Minimize the Constraints
}

\author{
M.G. Puri; J.R. Kadam; S.K. Deshmukh; P.M Zagade \\ Department of Extension Education, College of Agriculture, Dapoli, Ratnagiri- 415712, Maharashtra \\ DOI: 10.47856/ijaast.2021.v08i1.003
}

\begin{abstract}
This paper examines the constraints faced by the farmers in adaptation activities in response to climate change and their suggestions to minimize the constraints. The investigation was carried out in all three districts of the North Konkan Zone i.e. Raigad, Thane and Palghar. Two tahasils from each district and five villages from each tahasil were randomly selected to conduct the study. Majority of the respondents reported 'no information on weather forecast' and irregularity of extension services'. More than sixty per cent (63.33 percent) respondents mentioned 'lack of information about ill effects of climate change' followed by 'inadequate knowledge about recommended mitigation strategies' and 'lack of believe on current weather forecast system. Whereas, mitigating to climate change in agriculture as majority of the respondents suggested 'need of weekly metrological data', and demand 'regular and effective extension services', 'proper advisory system on climate change' followed by 'awareness among the people about ill effects of climate change and its consequences', and need 'proper government policy support during natural calamities'.
\end{abstract}

Keywords: Constraints, Farmers, Adaptation, Climate change, Suggestions, Minimize

\section{INTRODUCTION}

Agriculture is the most important sector in Indian economy that provides food and livelihood security to majority of its population. Agriculture places heavy burden on the environment in the process of providing humanity with food and fiber, while climate is the primary determinant of agricultural productivity. Given the fundamental role of agriculture in human welfare, concern has been expressed by federal agencies and others regarding the potential effects of climate change on agricultural productivity. In India, climate change has been putting additional stress on ecological and socioeconomic systems that already facing tremendous pressures due to rapid urbanization, industrialization and economic development. Climate change is predicted by scientists to have the main impact on agriculture, economy and livelihood of the populations of developing countries and India is one of them, where large parts of the population depend on climate sensitive sectors like agriculture and forestry 


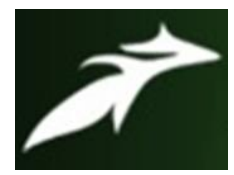

M.G. Puri et al, International Journal of Advances in Agricultural Science and Technology,

Vol.8 Issue.1, January-2021, pg. 23-28

ISSN: 2348-1358

Impact Factor: 6.057

NAAS Rating: 3.77

for livelihood. In order to understand how farmers would respond to climate change, it is essential to study farmers' perceptions on climate change and its impact on agriculture. As the understanding on global climate and its change is pre requisite to take appropriate initiatives to combat climate change. The only solution for these huge populations seems to be adequate and relevant adaptation strategies. Hence, the investigation entitled "Perception of farmers about climate change and its effect on agriculture in Konkan region of Maharashtra" was carried out in plateau, hilly and coastal area of Konkan of Maharashtra state.

\section{OBJECTIVE}

To study the constraints faced by the farmers in adaptation activities in response to climate change and their suggestions to minimize the constraints.

\section{METHODOLOGY}

The study was conducted in three selected districts of North Konkan Zone of Maharashtra State during the year 2017-18 and 2018-19. From each selected district 2 tahasils were selected, where 5 villages from each tehsil and 10 farmers from each village were considered to obtain a sample of 300 farmers as respondents who had 15 or more years of farming experience. The data collected from respondents through personal interview and group discussion were coded, tabulated and subjected to statistical analysis in accordance with the objectives of the study. This study was carried out to measure perception of farmers about climate change and effect of climate change on agriculture and allied activities considering as dependent variables.

\section{RESULT AND DISCUSSION}

\section{Constraints faced by the farmers in adaptation to climate change.}

The present study also assessed farmers constraints experienced by them in using various adaptation practices to mitigate adverse effect of climate change on agriculture and allied activities. The information received by the farmers on constraints was further ranked as per maximum number of responses obtained. 


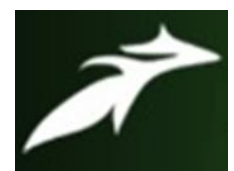

M.G. Puri et al, International Journal of Advances in Agricultural Science and Technology,

Vol.8 Issue.1, January-2021, pg. 23-28

ISSN: 2348-1358

Impact Factor: 6.057

NAAS Rating: 3.77

Table No. 1 Constraints faced by the farmers in adaptation to climate change

\begin{tabular}{|c|c|c|c|c|}
\hline Sl.No. & Constrains & Frequency & Percentage & Rank \\
\hline 1 & $\begin{array}{l}\text { No information on weather } \\
\text { forecast }\end{array}$ & 236 & 78.66 & I \\
\hline 2 & $\begin{array}{l}\text { Lack of information about ill } \\
\text { effects of climate change }\end{array}$ & 190 & 63.33 & III \\
\hline 3 & $\begin{array}{l}\text { No knowledge about } \\
\text { recommended mitigation } \\
\text { strategies }\end{array}$ & 162 & 54.00 & IV \\
\hline 4 & Limited resources & 102 & 34.00 & IX \\
\hline 5 & $\begin{array}{l}\text { Non availability of inputs in } \\
\text { time }\end{array}$ & 98 & 32.66 & $\mathrm{X}$ \\
\hline 6 & $\begin{array}{l}\text { Irregularity of extension } \\
\text { services }\end{array}$ & 215 & 71.66 & II \\
\hline 7 & $\begin{array}{l}\text { Less/no subsidies on desired } \\
\text { agricultural inputs }\end{array}$ & 110 & 36.66 & VIII \\
\hline 8 & $\begin{array}{l}\text { Poor government policies to } \\
\text { combat against natural } \\
\text { calamities }\end{array}$ & 118 & 39.33 & VII \\
\hline 9 & $\begin{array}{l}\text { Lack of believe on current } \\
\text { weather forecast system }\end{array}$ & 144 & 48.00 & V \\
\hline 10 & $\begin{array}{l}\text { No training programmes on } \\
\text { natural disaster management }\end{array}$ & 124 & 41.33 & VI \\
\hline
\end{tabular}

It is observed from the table 1 that, large majority of the respondents reported 'no information on weather forecast' 78.66 per cent and irregularity of extension services' (71.66 per cent). More than sixty per cent (63.33 percent) respondents mentioned 'lack of information about ill effects of climate change' followed by 'inadequate knowledge about recommended mitigation strategies' (54.00 per cent) and 'lack of believe on current weather forecast system (48.00 per cent). 'no training programmes on natural disaster management' (41.33 per cent), 'poor government policies to combat against natural calamities' (39.33 per cent). 'less/no subsidies on desired agricultural inputs' (36.66 per cent) 'limited resources' (34.00 per cent) and 'non availability of inputs in time', (32.00 per cent) were other constraints reported by the respondents. 


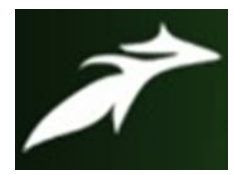

M.G. Puri et al, International Journal of Advances in Agricultural Science and Technology,

Vol.8 Issue.1, January-2021, pg. 23-28

ISSN: 2348-1358

Impact Factor: 6.057

NAAS Rating: 3.77

\section{Suggestions given by farmers to overcome the constraints.}

The farmers of the study area were also asked about their suggestions to overcome constrains faced by them in mitigating to climate change in agriculture.

Table No.2 Suggestions given by farmers to overcome the constraints

\begin{tabular}{|c|l|c|c|c|}
\hline Sl.No. & \multicolumn{1}{|c|}{ Suggestions } & Frequency & Percentage & Rank \\
\hline 1 & Need of weekly metrological data & 218 & 72.66 & I \\
\hline 2 & $\begin{array}{l}\text { Proper advisory system on } \\
\text { climate change }\end{array}$ & 182 & 60.66 & III \\
\hline 3 & $\begin{array}{l}\text { Regular training on disaster } \\
\text { management }\end{array}$ & 138 & 46.00 & VI \\
\hline 4 & $\begin{array}{l}\text { Provision of good quality } \\
\text { agricultural inputs on subsidized } \\
\text { rate and in time }\end{array}$ & 115 & 38.33 & VIII \\
\hline 5 & $\begin{array}{l}\text { Crop insurance scheme for all } \\
\text { crops }\end{array}$ & 107 & 35.66 & IX \\
\hline 6 & $\begin{array}{l}\text { Awareness among the people } \\
\text { about ill effects of climate change } \\
\text { and its consequences }\end{array}$ & 172 & 57.33 & IV \\
\hline 7 & $\begin{array}{l}\text { Regular and effective extension } \\
\text { services }\end{array}$ & 202 & 67.33 & II \\
\hline 8 & $\begin{array}{l}\text { Proper government policy support } \\
\text { during natural calamities }\end{array}$ & 156 & 52.00 & V VI \\
\hline 9 & $\begin{array}{l}\text { Need of location specific water } \\
\text { storage structure for utilization of } \\
\text { rainwater }\end{array}$ & 123 & 41.00 & \\
\hline
\end{tabular}

It is revealed from the table 2 that, large majority (72.66 per cent) of the respondents suggested 'need of weekly metrological data', while 67.63 per cent of the respondents demanded 'regular and effective extension services'. 'Proper advisory system on climate change' also reported by 60.66 per cent of the respondents followed by 57.33 per cent of the respondents suggested 'awareness among the people about ill effects of climate change and its consequences'. More than one half 52.00 per cent of the respondents need 'proper government policy support during natural calamities'. Other suggestions such as 'regular training programme on disaster management (46.00 per cent). Need of location specific water storage structure for utilization of rainwater (41.00 per cent). Provision of good quality 


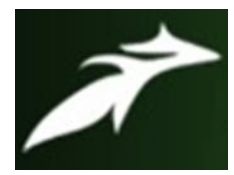

M.G. Puri et al, International Journal of Advances in Agricultural Science and Technology,

Vol.8 Issue.1, January-2021, pg. 23-28

ISSN: 2348-1358

Impact Factor: 6.057

NAAS Rating: 3.77

agricultural inputs on subsidized rate and in time (38.00 per cent) and crop insurance scheme for all crops (35.00 per cent) were also suggested by the respondents.

\section{CONCLUSION}

It was found in the investigation that more than sixty per cent (63.33 percent) respondents mentioned 'lack of information about ill effects of climate change' followed by 'inadequate knowledge about recommended mitigation strategies' and 'lack of believe on current weather forecast system. Whereas, mitigating to climate change in agriculture as majority of the respondents suggested 'need of weekly metrological data', and demand 'regular and effective extension services', 'proper advisory system on climate change' followed by 'awareness among the people about ill effects of climate change and its consequences', and need 'proper government policy support during natural calamities'.

\section{References}

[1]. Abhishek P.S. (2017)"Effect of climate change on Alphanso mango as perceived by the farmers from south Konkan Costal Zone of Maharashtra" M.Sc. (Agri.) thesis, Dr. Balasaheb Sawant Konkan Krishi Vidyapeeth, Dapoli.

[2]. Adger, W.N., Hug, S., Brown, K., Conway, D. and Hume, M. 2003. Adaptation to climate change in developing world. Progress in Development Studies 3 (3): 179-195. URL: http://dx.doi.org.

[3]. Gajendra T. H.(2011) Perspectives of farmer on effect of climate change on agriculture and livestock. M.Sc. (Agri.) thesis University of Agricultural Sciences, Dharwad.

[4]. Hassan, R. 2010. Implications of climate change for agricultural sector performance in Africa: policy challenges and research agenda. Journal of African Economies 19: 77-105.

[5]. Ishaya, S. and Abaje, I.B. 2008. Indigenous people's perception on climate change and adaptation strategies in Jema'a local government area of Kaduna State, Nigeria. Journal of Geography and Regional Planning 1(8): 138-43.

[6]. Kummar, A. (2010) Economics of Land Use and Cropping Pattern In Northern Transitional Zone Of Agriculture, Dharwad University Of Agriculture Sciences, Dharwad. 


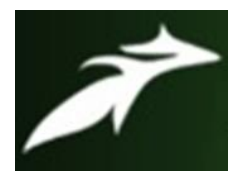

M.G. Puri et al, International Journal of Advances in Agricultural Science and Technology, Vol.8 Issue.1, January-2021, pg. 23-28

ISSN: 2348-1358

Impact Factor: 6.057

NAAS Rating: 3.77

[7]. Lathad A. M. (2018), "Farming system of tribal farmers from Palghar district, Maharashtra, M.Sc. (Agri.) thesis (unpublished) Dr. Balasaheb Sawant Konkan Krishi Vidyapeeth, Dapoli.

[8]. Mergewar, A. (2017) Cropping Pattern Followed by Awardee Farmers in Marathwada Region, M. Sc. (Ag) Thesis, College of Agriculture, Parbhani Vasantrao Naik Marathwada Krishi Vidyapeeth Parbhani- (M.S.). 